\title{
牧草中のエストロジェン様物質の投与によるハムスターの 正常雄と去勢雌の体成分の変化
}

\author{
萬田富 治* ・松本達 郎 \\ 東北大学農学部, 仙台市 980 \\ (1972. 5. 25 受付)
}

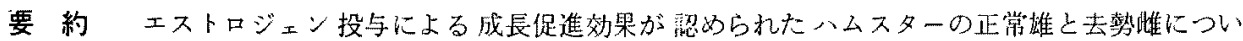
て, 体長, 大腿骨長および臓器重量と体成分に及政す diethylstielbestrol (DES) と牧草中のエストロ ジェン様物質 (ES) の影镜を比較した。

正常雄では DES, genistin およびアルファルファ抽出物（Al-E）の投与によって体長および大腿骨

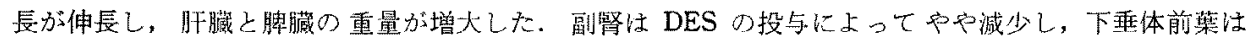
Al-E の投与によって增大したが，他の区閒には差がなかった。精巣および精のうの重量は DES の 投与によって減少したが, genistin と Al-E の投与によって逆に増大した。体成分は DES, genistin および Al-Eの投与によって各成分ともに増加したが，特に脂肪の增加が著しかった。脂肪の蓄積は皮 下脂肪が最も多く，精栄周囲脂肪がこ机についで多く，粲周囲㧍よび腸間膜の脂肪蓄積は少なかった。 体成分の比体重值では脂肪の割合のみが增加し，他の成分は対照区と差がなかった。

卵巣除去によって，体長，大腿骨長，腎臟が正常比に比べてやや減少したが，差は有意ではなかった。 仠臟と副腎重量が減少し，下垂体前葉は著しく增大した，体成分の割合は正常雌に比べて脂肪が有意に 増加し，FFS が減少し水分は変化しなかっだ，各部位の蓄積脂肪はいずれも増加する傾向が浔められ たが，特に監周囲脂肪は有意の增加を示した。

去勢此では DES, genistin および Al-E の投与によって体長拉よび大腿骨長恃伸長したが，比体重 值ではいずれも低下した，肝炡と腎臟重量は增大したが，本実験の用量では副腎と子宮重量は变らなが った，下垂体前葉は DES および genistin を投与しても変らなかったが，Al-E の投与によって增大 した，体成分では DES, genistin および Al-E の投与によって各成分ともに増加したが特に脂肪の増 加が多かった，体成分の比体垂值では水分が減少し，脂肪が增加した．FFS の比体重㒹は DES の投与.

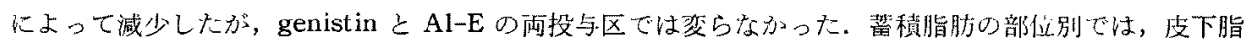
肪の䈏積が著しかった。

以上の結果から，エストロジェン投与に上って成長が促進された正常雄と去勢䧳の体長，大朖骨長打

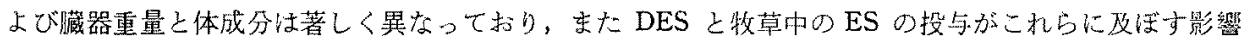
にも差異のあることが明らかにされだ。
\end{abstract}

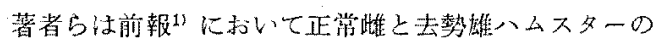
成長注牧草中エストロジェン様物㑭 (ES) 在投与しても 変らないが，正常雄と去勢崔八ムス夕一では成長促進効 果が認めら机ることを報告した。本報では正常雄上去勢 雌ハムスタ一を用いて, 体長, 大腿骨長および臟器重量 と体成分に及济す DES ES の影響を比較し，父の增 体の内容を検討した結果について報告する。

* 現在：農林省草地試験場

日畜会報，44，(2)：97-104.

\section{材料および方法}

实験材料は前実䮖1 でエストロジェン投与によって成 長促進㹝果の認められた幼若心ムスタ一の正常雄（実駼

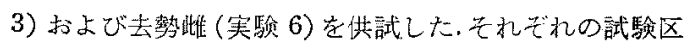
の内容は正常雄では, 対照区, DES $0.01 \mu \mathrm{g} / \mathrm{g}$ diet 投与 区, genistin $2 \mathrm{mg} / \mathrm{g}$ diet 投与区, アルファルファ抽出 物 (Al-E) $3 \mathrm{mg} / \mathrm{g}$ diet 投与区，Al-E $6 \mathrm{mg} / \mathrm{g}$ diet 投
1973. 2. 
与区の 5 区で，去勃雌では，正常雌対照区，去攀雌対照 区，去勢比 + DES $0.01 \mu \mathrm{g} / \mathrm{g}$ diet 投与区，去勢䧳十 genistin $2 \mathrm{mg} / \mathrm{g}$ diet 投与区, 去丞雃 $+\mathrm{Al}-\mathrm{E} 6 \mathrm{mg} / \mathrm{g}$ diet 投与区の 5 区である，供苚頭数怢各区いずれも 5 匹 ずつで, 60 日間の成長試験終了後, 前報21の方法に佂。 て体長, 大腿骨長およひ闭哭重量の測定々体成分の分析 を行なった。

\section{結果}

1. 幼若正常雄：前実験”で明らかにされたように DES 投与区, genistin 投与区および Al-E $6 \mathrm{mg}$ 投与 区のそれぞれ 3 区で成長促進効果が㒛められたが, Al-E $3 \mathrm{mg}$ 投与区の成長は促進され京加った。各区の体長

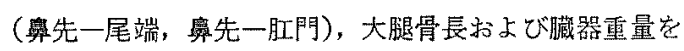
表 1 に示した，刘照区に比べて体重が堌加した 3 投与区 では，体長および大腿骨長ともに対照区よりも伸長し $(\mathrm{P}<0.05)$, 肝臓重量が増大した $(\mathrm{P}<0.05)$. 筒臓重量 む増大寸る傾向が認められたが差は有意でなかった，成 長促進效果が認められなかっった Al-E $3 \mathrm{mg}$ 投与区は体

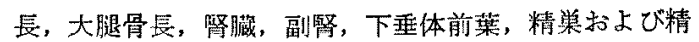
のうの各臟器重量はいずれも対照区と差がなかったが,

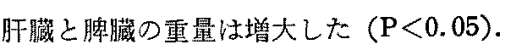

副㷂重量は各区間に有意差は認められなかったが, DES 投与区がやや減少した。下垂体前策重量は AI-E $6 \mathrm{mg}$ 投与区で增大し $(\mathrm{P}<0.05)$ ，他の区閒に差は認 められなかった。精巣执よび精のう重量注対照区に比べ $\tau$ DES 投与区で減少し $(\mathrm{P}<0.05) ， \mathrm{Al}-\mathrm{E}$ 投与区就よ び genistin 投与区の再区では逆に增大する傾向が認か られたが，差壮有意でなかった。

各区の体長, 大腿骨長叔よび臟器重量の比体重值を哀 2 に示した。体長, 大腿骨長, 肝臓, 腎臓, 脾臓の比体重 值は各区間に差は認められなかった，副腎重量の比体重 值は对照区に比べて各投与区ともに減少し $(P<0.05)$, 下垂体前葉重墨の比体重值は Al-E $6 \mathrm{mg}$ 投与区が增 大し $(\mathrm{P}<0.01)$ ，他の区間には差が認め玌なかった。精

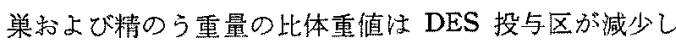
$(\mathrm{P}<0.05)$ ，他の区間には差が認められなかった。

各区の体成分の分析結果表表 3 に示した。各成分を絶

Table 1. Effect of oral administration of diethylstilbestrol, genistin and alfalfaextract on body length and organ weight of young male hamsters

\begin{tabular}{|c|c|c|c|c|c|c|}
\hline \multirow{3}{*}{ Item } & \multirow{3}{*}{ Control } & \multicolumn{4}{|c|}{ Treatment (per $\mathrm{g}$ diet) } & \multirow{3}{*}{ Significance } \\
\hline & & \multirow{2}{*}{$\begin{array}{c}\text { DES } \\
0.01 \mu \mathrm{g}\end{array}$} & \multirow{2}{*}{$\begin{array}{l}\text { Genistin } \\
2 \mathrm{mg}\end{array}$} & \multicolumn{2}{|c|}{ Alfalfa-extract } & \\
\hline & & & & $3 \mathrm{mg}^{\mathrm{a}}$ & $6 \mathrm{mg}^{3}$ & \\
\hline \multicolumn{7}{|l|}{ Body wt. (g) } \\
\hline Initial & $74.6 \pm 3.6^{d}$ & $72.2 \pm 6.2$ & $74.0 \pm 5.3$ & $75.6 \pm 3.2$ & $73.9 \pm 5.7$ & N.S. \\
\hline Final & $118.8 \pm 4.0$ & $130.2+4.3$ & $133.0 \pm 4.1$ & $122.3 \pm 3.9$ & $130.9 \pm 3.5$ & $* 1,4$ vs. $2,3,5$ \\
\hline \multicolumn{7}{|l|}{ Body length $(\mathrm{cm})$} \\
\hline Nose-Tail & $15.9 \pm 0.2$ & $17.0 \pm 0.4$ & $17.2 \pm 0.3$ & $16.0 \pm 0.2$ & $16.9 \pm 0.4$ & $* 1,4$ vs. $2,3,5$ \\
\hline Nose-Anus & $14.9 \pm 0.3$ & $16.1 \pm 0.2$ & $16.5 \pm 0.4$ & $15.1 \pm 0.8$ & $16.3 \pm 0.6$ & $* 1,4$ vs. $2,3,5$ \\
\hline Femur length $(\mathrm{cm})$ & $2.49 \pm 0.08$ & $2.70 \pm 0.03$ & $2.80 \pm 0.03$ & $2.56 \pm 0.05$ & $2.73 \pm 0.04$ & $* 1,4$ vs. $2,3,5$ \\
\hline \multicolumn{7}{|l|}{ Organs } \\
\hline Liver (g) & $5.51 \pm 0.27$ & $6.08 \pm 0.18$ & $6.20 \pm 0.15$ & $5.91 \pm 0.08$ & $6.10 \pm 0.21$ & $*_{1}$ vs. $2,3,4,5$ \\
\hline Kidneys (g) & $1.00 \pm 0.05$ & $1.10 \pm 0.08$ & $1.12 \pm 0.15$ & $1.08 \pm 0.22$ & $1.13 \pm 0.05$ & N.S. \\
\hline Spleen (mg) & $110 \pm 5$ & $115 \pm 7$ & $120 \pm 3$ & $120 \pm 3$ & $125 \pm 5$ & $*_{1}$ vs. $3,4,5$ \\
\hline Adrenals (mg) & $20.9 \pm 1.3$ & $18.0 \pm 2.2$ & $19.5 \pm 1.6$ & $20.4 \pm 2.0$ & $21.0 \pm 1.8$ & N.S. \\
\hline Pituitary $(\mathrm{mg})^{\mathfrak{c}}$ & $2.00 \pm 0.03$ & $2.20 \pm 0.07$ & $2.10 \pm 0.10$ & $2.00 \pm 0.08$ & $2.50 \pm 0.12$ & $* 1,2,3$ vs. 5 \\
\hline Testes (g) & $2.51 \pm 0.50$ & $1.82 \pm 0.09$ & $2.55 \pm 0.92$ & $2.61 \pm 0.08$ & $2.68 \pm 0.20$ & $*_{2}$ vs. $1,3,4,5$ \\
\hline $\begin{array}{l}\text { Seminal } \\
\text { vesicles }(g)\end{array}$ & $1.33 \pm 0.09$ & $0.93 \pm 0.08$ & $1.26 \pm 0.21$ & $1.43 \pm 0.10$ & $1.44 \pm 0.05$ & $*_{2}$ vs. $1,3,4,5$ \\
\hline
\end{tabular}

a : Equivalent to $0.33 \mathrm{~g}$ alfalfa meal dry matter

$\mathrm{b}$ : Equivalent to $0.66 \mathrm{~g}$ alfalfa meal dry matter

c : Anterior lobe of pituitary

d : Mean \pm S. D.

* $\mathrm{P}<0.05, \quad$ N.S.: Not significant 
牧草中のエストロジェンの影響

Table 2. Effect of oral administration of diethylstilbestrol, genistin and alfalfa-extract on body length and organ weight as percentages of body weight in young male hamsters

\begin{tabular}{|c|c|c|c|c|c|c|}
\hline \multirow{3}{*}{ Item } & \multirow{3}{*}{ Control } & \multicolumn{4}{|c|}{ Treatment (per $g$ diet) } & \multirow{3}{*}{ Significance } \\
\hline & & \multirow{2}{*}{$\begin{array}{c}\text { DES } \\
0.01 \mu \mathrm{g}\end{array}$} & \multirow{2}{*}{$\begin{array}{c}\text { Genistin } \\
2 \mathrm{mg}\end{array}$} & \multicolumn{2}{|c|}{ Alfalfa-extract } & \\
\hline & & & & $3 \mathrm{mg}^{\mathrm{a}}$ & $6 \mathrm{mg}^{\mathrm{b}}$ & \\
\hline \multicolumn{7}{|l|}{$\begin{array}{l}\text { Body length } \\
(\mathrm{cm} / 100 \mathrm{~g} \text { body wt. })\end{array}$} \\
\hline Nose-Tail & $13.4 \pm 0.6^{\mathrm{d}}$ & $13.1 \pm 0.8$ & $12.9 \pm 0.5$ & $13.1 \pm 0.7$ & $12.9 \pm 0.3$ & N.S. \\
\hline Nose-Anus & $12.5 \pm 0.4$ & $12.4 \pm 0.3$ & $12.4 \pm 0.2$ & $12.4 \pm 0.5$ & $12.5 \pm 0.4$ & N.S. \\
\hline $\begin{array}{l}\text { Femur length } \\
(\mathrm{cm} / 100 \mathrm{~g} \text { body } w t .)\end{array}$ & $2.10 \pm 0.05$ & $2.07 \pm 0.04$ & $2.11 \pm 0.03$ & $2.09 \pm 0.01$ & $2.09 \pm 0.04$ & N.S. \\
\hline \multicolumn{7}{|l|}{ Organs } \\
\hline Liver $(\%)$ & $4.64 \pm 0.50$ & $4.67 \pm 0.31$ & $4.66 \pm 0.45$ & $4.83 \pm 0.80$ & $4.66 \pm 0.29$ & N.S. \\
\hline Kidneys (\%) & $0.84 \pm 0.07$ & $0.85 \pm 0.05$ & $0.84 \pm 0.06$ & $0.88 \pm 0.03$ & $0.86 \pm 0.06$ & N.S. \\
\hline Spleen (mg\%) & $93 \pm 4$ & $88 \pm 3$ & $90 \pm 5$ & $98 \pm 4$ & $96 \pm 7$ & N.S. \\
\hline Adrenals (mg\%) & $17.6 \pm 0.8$ & $13.8 \pm 0.5$ & $14.7 \pm 0.3$ & $16.7 \pm 0.2$ & $16.0 \pm 0.3$ & $* 1$ vs. $2,3,4,5$ \\
\hline Pituitary $(\mathrm{mg} \%)^{\circ}$ & $1.68 \pm 0.05$ & $1.68 \pm 0.08$ & $1.58 \pm 0.12$ & $1.63 \pm 0.06$ & $1.91 \pm 0.11$ & $* * 1,2,3,4$ vs. 5 \\
\hline Testes (\%) & $2.11 \pm 0.10$ & $1.40 \pm 0.21$ & $1.92 \pm 0.22$ & $2.13 \pm 0.08$ & $2.05 \pm 0.13$ & $*_{2}$ vs. $1,3,4,5$ \\
\hline $\begin{array}{l}\text { Seminal } \\
\text { vesicles }(\%)\end{array}$ & $1.12 \pm 0.02$ & $0.71 \pm 0.03$ & $0.95 \pm 0.07$ & $1.17 \pm 0.05$ & $1.10 \pm 0.10$ & ${ }^{*} 2$ vs. $1,3,4,5$ \\
\hline
\end{tabular}

Table 3. Effect of oral administration of diethylstilbestrol, genistin and alfalfa-extract on body composition of young male hamsters

\begin{tabular}{|c|c|c|c|c|c|c|}
\hline \multirow{3}{*}{ Item } & \multirow{3}{*}{ Control } & \multicolumn{4}{|c|}{ Treatment (per $\mathrm{g}$ diet) } & \multirow{3}{*}{ Significance } \\
\hline & & \multirow{2}{*}{$\begin{array}{c}\text { DES } \\
0.01 \mu \mathrm{g}\end{array}$} & \multirow{2}{*}{$\begin{array}{c}\text { Genistin } \\
2 \mathrm{mg}\end{array}$} & \multicolumn{2}{|c|}{ Alfalfa-extract } & \\
\hline & & & & $3 \mathrm{mg}^{\mathrm{a}}$ & $6 \mathrm{mg}^{\mathrm{b}}$ & \\
\hline \multicolumn{7}{|c|}{ Weight of body composition ( $g$ ) } \\
\hline & 1 & 2 & 3 & 4 & 5 & \\
\hline Water & $73.9 \pm 1.4^{\mathrm{d}}$ & $75.8 \pm 2.0$ & $76.3 \pm 2.3$ & $74.2 \pm 2.1$ & $76.0 \pm 1.8$ & $* 1$ vs. $2,3,5$ \\
\hline Fat & $19.1 \pm 2.5$ & $27.0 \pm 3.1$ & $29.0 \pm 2.2$ & $23.1 \pm 1.3$ & $28.1 \pm 3.3$ & $* * 1,4$ vs. $2,3,5$ \\
\hline $\mathrm{FFS}^{\mathrm{c}}$ & $22.9 \pm 1.6$ & $24.2 \pm 1.1$ & $24.8 \pm 1.0$ & $23.3 \pm 1.3$ & $23.3 \pm 0.8$ & N.S. \\
\hline \multicolumn{7}{|c|}{ Body composition as $\%$ of body weight } \\
\hline Water & $63.8 \pm 2.0$ & $59.7 \pm 2.3$ & $58.7 \pm 3.1$ & $61.5 \pm 1.8$ & $59.7 \pm 2.2$ & N.S. \\
\hline Fat & $16.5 \pm 1.9$ & $21.3 \pm 2.1$ & $22.3 \pm 3.0$ & $19.2 \pm 1.5$ & $22.1 \pm 1.9$ & $* * 1$ vs. $2,3,5$ \\
\hline FFS & $19.7 \pm 0.8$ & $19.1 \pm 0.5$ & $19.1 \pm 1.2$ & $19.3 \pm 0.8$ & $18.2 \pm 1.1$ & N.S. \\
\hline
\end{tabular}

* $\mathrm{P}<0.05, \quad * * \mathrm{P}<0.01, \quad$ N.S.: Not significant

$\mathrm{a}$ : Equivalent to $0.33 \mathrm{~g}$ alfalfa meal dry matter

$\mathrm{b}$ : Equivalent to $0.66 \mathrm{~g}$ alfalfa meal dry matter

c : Fat-free solid

d : Mean \pm S. D. 


\section{萬田・松本}

Table 4. Effect of oral administration of diethylstilbestrol, genistin and alfalfa-extract on amount and distribution of body fat in young male hamsters

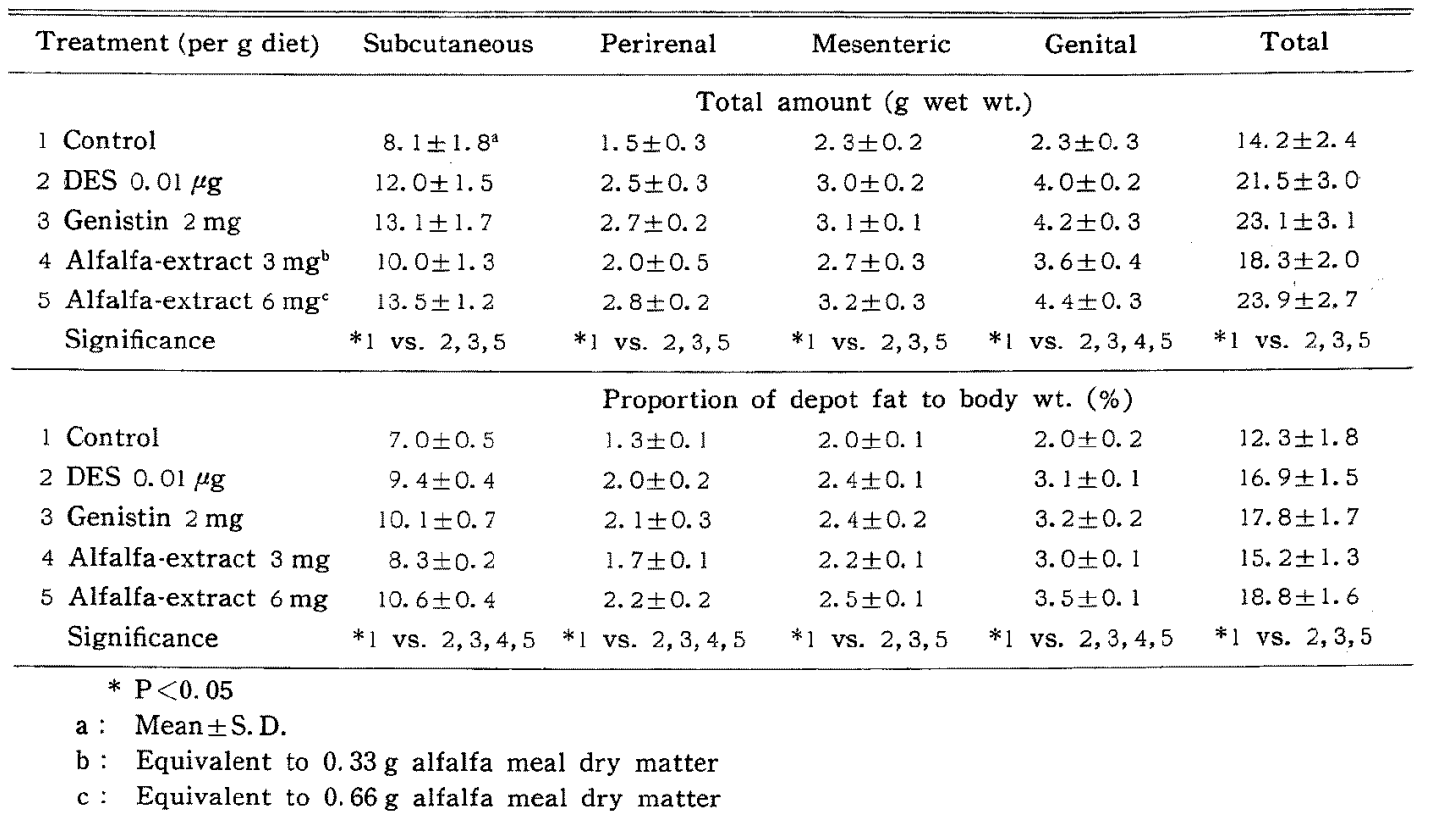

Table 5. Effect of oral administration of diethylstilbestrol, genistin and alfalfaextract on body length and organ weight of young spayed hamsters

\begin{tabular}{|c|c|c|c|c|c|c|}
\hline \multirow{3}{*}{ Item } & \multirow{3}{*}{$\begin{array}{l}\text { Intact } \\
\text { female }\end{array}$} & \multicolumn{4}{|c|}{ Spayed } & \multirow{3}{*}{ Significance } \\
\hline & & \multirow[b]{2}{*}{ Control } & \multicolumn{3}{|c|}{ Treatment (per $\mathrm{g}$ diet) } & \\
\hline & & & $\begin{array}{c}\text { DES } \\
0.01 \mu \mathrm{g}\end{array}$ & $\begin{array}{l}\text { Genistin } \\
2 \mathrm{mg}\end{array}$ & $\begin{array}{l}\text { Alfalfa-extract } \\
6 \mathrm{mg}^{\mathrm{c}}\end{array}$ & \\
\hline \multicolumn{7}{|l|}{ Body wt. (g) } \\
\hline Initial & $51.5 \pm 4.7^{\mathrm{a}}$ & $47.7 \pm 1.9$ & $48.7 \pm 3.3$ & $49.5 \pm 4.3$ & $50.0 \pm 4.1$ & N.S. \\
\hline Final & $116.2 \pm 5.1$ & $113.4 \pm 4.0$ & $140.6 \pm 4.9$ & $138.2 \pm 5.2$ & $142.0 \pm 3.8$ & $* 1,2$ vs. $3,4,5$ \\
\hline \multicolumn{7}{|l|}{ Body length $(\mathrm{cm})$} \\
\hline Nose-Tail & $15.9 \pm 0.3$ & $15.6 \pm 0.3$ & $16.6 \pm 0.2$ & $16.6 \pm 0.3$ & $16.7 \pm 0.4$ & $*_{2}$ vs. $3,4,5$ \\
\hline Nose-Anus & $13.8 \pm 0.4$ & $13.4 \pm 0.3$ & $14.3 \pm 0.3$ & $14.5 \pm 0.2$ & $14.6 \pm 0.4$ & $*_{2}$ vs. $3,4,5$ \\
\hline Femur length (cm) & $2.42 \pm 0.02$ & $2.39 \pm 0.10$ & $2.49 \pm 0.02$ & $2.50 \pm 0.03$ & $2.49 \pm 0.01$ & $* 2$ vs. $3,4,5$ \\
\hline \multicolumn{7}{|l|}{ Organs } \\
\hline Liver (g) & $5.82 \pm 0.42$ & $4.87 \pm 0.40$ & $5.81 \pm 0.33$ & $7.00 \pm 0.50$ & $6.33 \pm 0.22$ & *2 vs. $1,3,4,5$ \\
\hline Kidneys (g) & $1.00 \pm 0.04$ & $0.91 \pm 0.05$ & $1.08 \pm 0.02$ & $1.20 \pm 0.05$ & $1.10 \pm 0.03$ & $*_{2}$ vs. $3,4,5$ \\
\hline Spleen (mg) & $139 \pm 7$ & $143 \pm 5$ & $151 \pm 6$ & $170 \pm 11$ & $162 \pm 5$ & $* 1$ vs. $3,4,5$ \\
\hline Adrenals (mg) & $10.3 \pm 0.5$ & $8.3 \pm 0.8$ & $9.1 \pm 0.5$ & $8.9 \pm 0.3$ & $9.3 \pm 0.4$ & $* 1$ vs. $2,3,4,5$ \\
\hline Pituitary $(\mathrm{mg})^{\mathrm{b}}$ & $3.80 \pm 0.07$ & $6.00 \pm 0.10$ & $6.10 \pm 0.11$ & $6.20 \pm 0.08$ & $6.40 \pm 0.09$ & $\left(\begin{array}{ll}* 1 & \text { vs. } 2,3,4,5, \\
* 2 & \text { vs. } 5\end{array}\right.$ \\
\hline Uterus (mg) & $465 \pm 28$ & $46 \pm 5$ & $54 \pm 7$ & $51 \pm 5$ & $45 \pm 7$ & $* * * 1$ vs. $2,3,4,5$ \\
\hline $\begin{array}{l}* \mathrm{P}<0.05, \\
\mathrm{a}: \text { Mean } \pm \mathrm{S} . \mathrm{I} \\
\mathrm{b}: \text { Anterior } \\
\mathrm{c}: \text { Equivalent }\end{array}$ & $\begin{array}{l}* * * \mathrm{P}<0.001 \text {, } \\
\mathrm{D} \text {. } \\
\text { lobe of pituitar } \\
\text { it to } 0.66 \mathrm{~g} \text { alfa }\end{array}$ & N.S.: Not & ignificant & & & \\
\hline
\end{tabular}


対量で比較すると，水分および脂肪は刘照区に比べて DES 投与区，genistin 投与区および Al-E $6 \mathrm{mg}$ 投与区 の3区で增加し $(\mathrm{P}<0.05)$, 特に脂肪の増加が著しか。 犬. Al-E $3 \mathrm{mg}$ 投与区では脂肪の增加する傾向が認め られたが，有意ではなかった，次に各区の体成分を比体 重值で比較すると，脂肪を除いた他の成分の比体重值は 各区間に差はなかったが，脂肪の比体重值は DES 投与 区で $4.8 \%$, genistin 投与区で $5.8 \%$ ，AI-E $3 \mathrm{mg}$ 投 与区で $2.7 \%$ Al-E $6 \mathrm{mg}$ 投与区では 5.6\% それ艺れ 対照区上り增加した。

各成分のうち，いずれの投与区でも脂肪の蓄積が著し 加ったので，脂肪各部位別（皮下，腎周囲，腸間膜，

精巣周囲）に分けてそれぞれの湿重量夌測定し，その結 果を表 4 に示した．Al-E $3 \mathrm{mg}$ 投与区を除いた 3 投与. 区では対照区に比べて皮下脂肪の蓄積量が最む多く，精 单周囲脂肪がこれについで多く，腎周团がよび腸間膜脂 肪の蓄積量は少なかった。

2. 幼若去勢雌：前実娩1で明らかにされたように卵 宩除去しても体重は正常豼と変らないが，去勢㸕にエス トロジェンを投与することによって成最が促進された。 各区の体長 (家先一尾端, 鼻先一肛門)，大腿骨長および 臓器重量を表 5 に示した。体長よよび大腿骨長の伸長察 は卵巣除去によって減少したが，去勢䊒対照区に比べて
各投与区では増加した $(\mathbf{P}<0.05)$. 肝堿重量は卵巣除去 によ。て隇少し $(\mathrm{P}<0.05)$ ，尘樊此の各投与区ではいず れも增加した $(\mathrm{P}<0.05)$. 筒臟重量は畉楽除去しても变 らなかったが，去効雌对照区に比べて各投与区るむに増 大した $(\mathrm{P}<0.05)$. 副腎重量は卵策除去に上って隇少し $(P<0.05)$ ，去勢雃の各区間には差が認められなかった。 下垂体前葉重量は卵宩除去によ。て著しく增大し，去勢 雌对照区に比ベて A1-E 投与区が增大した $(\mathrm{P}<0.05)$ が，他の名投与区では去勢比対照区と差がなかった。子 宮重量江即䉾除去に上って著しく減少したが，去勢唯の 各区間には差はなく, DES, genistin 括よび Al-E 投

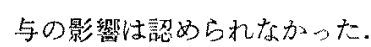

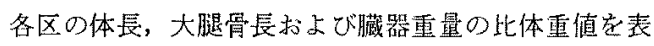
6 に示した．体長および大腿骨長の比体重值は正常倠と 去攀比の両対照区間には差がなかったが，各投与区では いずれも減少した $(P<0.05)$. 肝蔵重量の比体重值は卵巣 除去に上って減少し $(\mathrm{P}<0.05)$ ，去勢䧳刘照区に比べて genistin 投与区が増大し $(P<0.05)$ ，他の各投与区では 去勢雌対照区と差がなかった。.腎臟および脾㩔重量の比

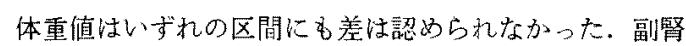
重量の比体重值は卵单除去によって減少し $(\mathrm{P}<0.05)$, 去勢䧳対照区と备投与区間に活差前認められなかった。 下垂体前䒚重量の比体重值は卵紧除去によって增大し

Table 6. Effect of oral administration of diethylstilbestrol, genistin and alfalfa-extract on body length and organ weight as percentages of body weight in young spayed hamsters

\begin{tabular}{|c|c|c|c|c|c|c|}
\hline \multirow{3}{*}{ Item } & \multirow{3}{*}{$\begin{array}{l}\text { Intact } \\
\text { female }\end{array}$} & \multicolumn{4}{|c|}{ Spayed } & \multirow{3}{*}{ Significance } \\
\hline & & \multirow[b]{2}{*}{ Control } & \multicolumn{3}{|c|}{ Treatment (per $\mathrm{g}$ diet) } & \\
\hline & & & $\begin{array}{c}\text { DES } \\
0.01 \mu \mathrm{g}\end{array}$ & $\begin{array}{l}\text { Genistin } \\
2 \mathrm{mg}\end{array}$ & $\begin{array}{l}\text { Alfalfa-extract } \\
6 \mathrm{mg}^{\mathrm{c}}\end{array}$ & \\
\hline \multicolumn{7}{|l|}{$\begin{array}{l}\text { Body length } \\
(\mathrm{cm} / 100 \mathrm{~g} \text { body wt. })\end{array}$} \\
\hline Nose-Tail & $13.7 \pm 0.6^{\mathrm{a}}$ & $13.8 \pm 0.10$ & $11.7 \pm 0.3$ & $12.0 \pm 0.3$ & $11.7 \pm 0.3$ & $* 1,2$ vs. $3,4,5$ \\
\hline Nose-Anus & $12.0 \pm 0.4$ & $11.9 \pm 0.5$ & $10.2 \pm 0.2$ & $10.5 \pm 0.3$ & $10.3 \pm 0.4$ & $* 1,2$ vs. $3,4,5$ \\
\hline $\begin{array}{l}\text { Femur length } \\
(\mathrm{cm} / 100 \mathrm{~g} \text { body wt. })\end{array}$ & $2.08 \pm 0.03$ & $2.12 \pm 0.05$ & $1.76 \pm 0.10$ & $1.78 \pm 0.03$ & $1.78 \pm 0.08$ & $* 1,2$ vs. $3,4,5$ \\
\hline \multicolumn{7}{|l|}{ Organs } \\
\hline Liver (\%) & $5.01 \pm 0.30$ & $4.30 \pm 0.23$ & $4.13 \pm 0.31$ & $4.93 \pm 0.20$ & $4.58 \pm 0.20$ & $* 1$ vs., $2 * 2$ vs. 4 \\
\hline Kidneys (\%) & $0.86 \pm 0.10$ & $0.80 \pm 0.08$ & $0.78 \pm 0.06$ & $0.84 \pm 0.07$ & $0.80 \pm 0.10$ & N.S. \\
\hline Spleen (mg\%) & $120 \pm 10$ & $126 \pm 11$ & $107 \pm 7$ & $117 \pm 6$ & $120 \pm 5$ & N.S. \\
\hline Adrenals (mg\%) & $8.9 \pm 0.8$ & $7.3 \pm 0.5$ & $6.5 \pm 0.2$ & $6.3 \pm 0.3$ & $6.5 \pm 0.4$ & $* 1$ vs. $2,3,4,5$ \\
\hline Pituitary $(\mathrm{mg} \%)^{\mathrm{b}}$ & $3.27 \pm 0.06$ & $5.29 \pm 0.30$ & $4.34 \pm 0.20$ & $4.41 \pm 0.18$ & $4.51 \pm 0.09$ & $\left(\begin{array}{ll}* 1 & \text { vs. } 2,3,4,5 \\
* 2 & \text { vs. } 3,4,5\end{array}\right.$ \\
\hline Uterus (mg\%) & $400 \pm 47$ & $41 \pm 7$ & $38 \pm 6$ & $33 \pm 3$ & $36 \pm 5$ & $* * * 1$ vs. $2,3,4,5$ \\
\hline $\begin{array}{l}* \mathrm{P}<0.05 \\
\mathrm{a}: \text { Mean } \pm \mathrm{S} . \mathrm{D} \\
\mathrm{b}: \text { Anterior } \mathrm{l} \\
\mathrm{c}: \text { Equivalent }\end{array}$ & $P<0.001$ & N.S.: Not & gnificant & & & \\
\hline
\end{tabular}


$(\mathrm{P}<0.05)$ ，去勢嶉対照区に比べて各投与区ではいずれ

も減少した $(P<0.05)$.

各区の体成分の分析結果を表 7 に示した，各成分定絶 対量で比較すると，水分は卵巣除去によってやや減少し たが差は有意でなかった．去勢雌対照区に比べて各投与.
区ともに増加した（P<0.05）．脂肪は期栄除去によって 増加し $(\mathrm{P}<0.05)$, 去攀崔対照区に比べて各投与区で著し く增加した.FFSは卵栄除去によってやや減少し，去智此 対照区に比べて各投与区ともに増加した $(\mathrm{P}<0.05)$. 次に 各区の体成分比体重值で比較すると, 水分の比体重值

Table 7. Effect of oral administration of diethylstilbestrol, genistin and alfalfa-extract on body composition of young spayed hamsters

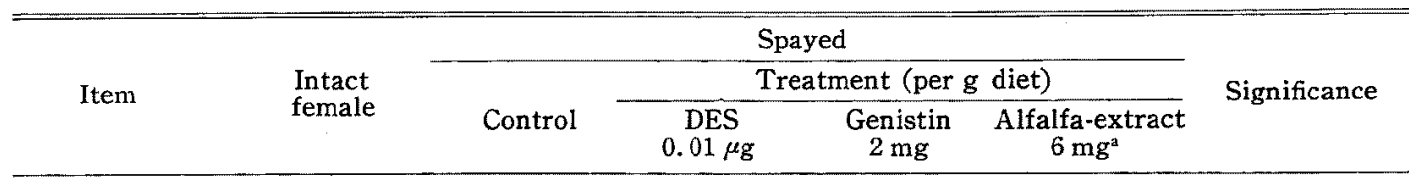

Weight of body composition (g)

$1 \quad 2 \quad 3 \quad 4 \quad 5$

\begin{tabular}{|c|c|c|c|c|c|c|}
\hline Water & $66.6 \pm 4.5^{\mathrm{c}}$ & $61.4 \pm 3.7$ & $69.5 \pm 5.0$ & $69.7 \pm 4.2$ & $68.9=3.9$ & $*_{2}$ vs. $3,4,5$ \\
\hline Fat & $22.7 \pm 2.1$ & $27.7 \pm 1.8$ & $43.4 \pm 4.2$ & $42.3 \pm 3.0$ & $41.5 \pm 4.0$ & $\left(\begin{array}{l}*^{*} 1 \text { vs. } 2 \\
* * 2 \text { vs. } 3,4,5\end{array}\right.$ \\
\hline FFS $^{b}$ & $22.4 \pm 1.5$ & $20.2 \pm 1.2$ & $22.9 \pm 0.9$ & $25.0 \pm 1.1$ & $23.3 \pm 0.8$ & $* 2$ vs. $3,4,5$ \\
\hline & \multicolumn{6}{|c|}{ Body composition as $\%$ of body weight } \\
\hline Water & $59.6 \pm 2.3$ & $56.2 \pm 2.0$ & $51.2 \pm 1.5$ & $50.9 \pm 2.1$ & $51.6 \pm 1.8$ & \multirow{3}{*}{$\begin{array}{l}* 2 \text { vs. } 3,4,5 \\
*_{1}^{*} \text { vs. } 2 \\
* 2 \text { vs. } 3,4,5 \\
\left(\begin{array}{ll}* 1 & \text { vs. } 2 \\
* 2 & \text { vs. } 3\end{array}\right.\end{array}$} \\
\hline Fat & $20.3 \pm 1.6$ & $25.3 \pm 1.4$ & $32.0 \pm 2.5$ & $30.9 \pm 1.7$ & $31.1 \pm 1.8$ & \\
\hline FFS & $20.1 \pm 0.9$ & $18.5 \pm 0.7$ & $16.9 \pm 0.3$ & $18.3 \pm 0.5$ & $17.4 \pm 0.4$ & \\
\hline
\end{tabular}

* $\mathrm{P}<0.05, \quad * * \mathrm{P}<0.01$

a : Equivalent to $0.66 \mathrm{~g}$ alfalfa meal dry matter

b: Fat-free solid

c: Mean \pm S. D.

Table 8. Effect of oral administration of diethylstilbestrol, genistin and alfalfa-extract on the amount and distribution of body fat in young spayed hamsters

\begin{tabular}{|c|c|c|c|c|}
\hline Treatment (per $\mathrm{g}$ diet) & Subcutaneous & Perirenal & Mesenteric & Total \\
\hline & \multicolumn{4}{|c|}{ Total amount ( $\mathrm{g}$ wet wt.) } \\
\hline 1 Intact female & $10.9 \pm 2.0^{6}$ & $2.5 \pm 0.2$ & $2.7 \pm 0.3$ & $17.1 \pm 3.0$ \\
\hline \multicolumn{5}{|l|}{ Spayed } \\
\hline 2 Control & $12.9 \pm 1.8$ & $3.4 \pm 0.4$ & $3.1 \pm 0.2$ & $19.4 \pm 2.5$ \\
\hline $3 \mathrm{DES} 0.01 \mu \mathrm{g}$ & $21.5 \pm 3.5$ & $5.8 \pm 0.3$ & $5.0 \pm 0.4$ & $32.3 \pm 4.1$ \\
\hline 4 Genistin $2 \mathrm{mg}$ & $22.0 \pm 4.0$ & $6.0 \pm 0.7$ & $5.3 \pm 0.3$ & $33.3 \pm 3.8$ \\
\hline 5 Alfalfa-extract $6 \mathrm{mg}^{3}$ & $19.3 \pm 3.7$ & $6.1 \pm 0.5$ & $5.1 \pm 0.3$ & $30.5 \pm 4.0$ \\
\hline Significance & $* * 2$ vs. $3,4,5$ & $\begin{array}{l}*_{2} \text { vs. } 3,4,5 \\
*_{1} \text { vs. } 2\end{array}$ & $*_{2}$ vs. $3,4,5$ & $* * 2$ vs. $3,4,5$ \\
\hline
\end{tabular}

1 Intact female

Spayed

2. Control

3 DES $0.01 \mu \mathrm{g}$

4 Genistin $2 \mathrm{mg}$

5 Alfalfa-extract $6 \mathrm{mg}$

Significance

\section{Proportion of depot fat to body wt. (\%)}

$\begin{array}{llll}9.8 \pm 1.5 & 2.2 \pm 0.1 & 2.4 \pm 0.2 & 15.3 \pm 2.0 \\ 11.8 \pm 1.4 & 3.1 \pm 0.2 & 2.8 \pm 0.1 & 17.8 \pm 2.2 \\ 15.8 \pm 2.0 & 4.3 \pm 0.2 & 3.7 \pm 0.3 & 23.8 \pm 1.8 \\ 16.1 \pm 1.9 & 4.4 \pm 0.5 & 3.9 \pm 0.3 & 24.3 \pm 2.0 \\ 14.4 \pm 2.1 & 4.6 \pm 0.3 & 3.8 \pm 0.5 & 22.8 \pm 1.5 \\ * 2 \text { vs. } 3,4,5 & * 2 \text { vs. } 3,4,5 & * 2 \text { vs. } 3,4,5 & * 2 \text { vs. } 3,4,5 \\ & * 1 \text { vs. } 2 & * 1 \text { vs. } 2 & \end{array}$

* $\mathrm{P}<0.05, \quad$ ** $\mathrm{P}<0.01$

$\mathrm{a}$ : Equivalent to $0.66 \mathrm{~g}$ alfalfa meal dry matter

b : Mean \pm S. D. 
牧草中のエストロジェンの影響

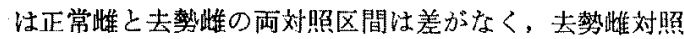
区に比べて各投与区ともに減少した $(\mathrm{P}<0.05)$. 脂肪の 比体重值は卵巣除去によ。て增加し $(\mathrm{P}<0.05)$, 去势雃 対照区に比べて各投与区ともに增加した（P<0.05）.

FFS の比体重值注卵巣除去によって減少し $(\mathrm{P}<0.05)$, 去勢雌対照区に比べて DES 投与区で減少した $(P<0.05)$ が他の投与区では差は認められなかった。

去勢此倠の場合, DES, genistin およびAl-Eの投与によ って脂肪が著しく增加したので，脂肪名部位別(皮下， 腎周囲，腸間膜）に分けてそれぞれの湿重量定測定し た.表8に示したとおり，エストロジェンの投与によ。 て皮下脂肪が最も多く蓄積され $(\mathrm{P}<0.01)$ ，これに比べ て腎周囲脂肪と腸聞膜脂肪の 蓄積量は少なかった $(\mathrm{P}<$ 0.05). 卯巣除去によって腎周囲脂肪が増加し $(P<0.05)$, 皮下脂肪と腸間膜脂肪もや堌加する傾向が認められた が差性有意ではなかった。

\section{考察}

DES, genistin および Al-E の投与によって成長が促 進された正常雄和よび去勢唯の体長，大腿骨長および藏 器重量と体成分は著しく変化し,さらにエストロジェン の種類による差異のあることが判明した，正常雄および 去勢雌ともにエストロジェンの投与によって体長と大腿 骨長が伸長したが，伸長量恃去勢雌よりも正常雄の方が 大きかった。体長と大腿骨長は咸形成の指標として測定 したが，エストロジェンに対する骨形成促進反応は去勎 雌よりも正常雄の方方高かったるの上推察される。

LoTz and Comar ${ }^{3)}$ 活子筩羊に estradiol $37 \sim 171$ 日間にわたって投与した結果，大腿骨端の䯣骨の形成が 促進され，之の骨の量的增加は estradiol D投与量および 投与期間とほぼ平行していることを認め，この骨の形成 は主として正常の骨吸收抑制と新しい骨の形成分促進さ れた結果方きる骨膜性の骨の発育と，正常の骨吸収の阻 止によって执こる大腿骨の骨幹端の軟骨性の骨の形成促 進の結果であるう之推察している。ウサギの実験では estrone の投与によって大腿骨が伸長し，その無機物量 む増加したことが報告されている゙).

哺乳中のラットの骨人の ${ }^{45} \mathrm{Ca}$ のとりこみはエストロ ジェン投与によって著しく促進され，血中 ${ }^{46} \mathrm{Ca}$ の濃度 も上昇する゙，また，エストロジェンは学の成展のみで はなく，骨の筫的な変化にも関与している。エストロジ エンはマウスの骨の密度を高める作用があるが，この作 用は estrone が最も強く, DES は最毛弱いとされてい る6)。乙れらェストロジェンの骨に対する作用は多くの 動物に認められているが，倛試動物の種類や性別，投与
量，投与方法などによって成縜は必ずしも一致しない。 しかしここれらの竍告は正常雄八ムスターの骨成辰がエ ストロジェン投与によって促進されたことを支持するる のと考えられる。亦た，エストロジェンが蛋白質代謝に 対して明らかな同化あるいは異化作用があるが否か、， 今のところ決定的な証明怯なされていない，たとえば子 宮のような特殊な標的縅器に対する肥大作用を别之すれ ば，企身的な体重増加作用はそれほど明らかではない。 もちろん体重增加作用荖証めて，エストロジェンに蛋白

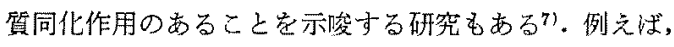
反知動物を用いた奏験ではエストロジェン投与によって 体重唯大し, 窒素の出納它正にしてその体内蓄積安增 加する作用のあることが明らかにされている8,91. しか し，単倜動物ではエストロジェンが逆に体重增加家抑制 する.八ムスタ一の場合は反㸷動物に類似している。

エストロジェンの投与によって正常雄と去勢睢の脂肪 が著しく蓄積され，蓄積量は去勢雌の方が顕著であっ た。このようにハムスターの場合はェストロジェンによ る脂肪蓄稓作用が認められたのであるが，エストロジェ ンと脂質代謝との関係については今俊に残された問題か 多い，正常動物にエストロジェンを注射した実䮦では血 清コレステロールやリン脂買が上萃するという報告もあ るが10,111，それは作用が一過性のものであったり，ま た，逆にコレステロールの低下を報告している研究者も 少なくない12，13)，徉ってェストロジェンが直接に体成分 の增加空促進するよりも，むし万間接的な作用の方が問 題になるといえる。

本実験で明らかにされたようにエストロジェンがハ ムスダーの体長, 大腿骨長および臟器重量と体成分に及 ほ壬影樂性别，去勢の有無や成長促進効果の有無など によって著しく異なり，また DES と牧草中の ES との 間に若干の差琪が認められた。促って，それでれの動物 の状態ごこにニストロジェンの作用を解明する必要があ るものと考えられる。また，いずれの実駰も投与期間が 長期 (60日間) にわたったことから, 各測定部位のらち エストロジェンの作用が途中で消失するものも考えられ るので，ェストロジェン投与後の体長，大腿骨長放よび 微器重量と体成分の経時的な推移老明らかにする実験が 必要である。

\section{文献}

1）萬田富治・松本详郎，日畜会報 44：1-10。1973.

2）萬田富治・松本達郎，日畜会竍 44：11-18. 1973.

3) Lotz, W.E., and C.L. Comar, Fed Proc 17: 100. 1958. 
4) Campbell, I. L., and C. W. Turner, The relation of the endocrine system to the regulation of calcium metabolism 102-107. Mo Agr Exp Sta Res Bull. 352. 1942.

5) Manunta, G., J. Saroff, and C.W. Turner, Proc Soc Exp Biol Med 94: 788-789. 1957.

6) Edgren, R.A., and D. W. Calhoun, Endocrinology 59: 631-636. 1956.

7) Clegg, M.T., and H.H. Cole, J Anim Sci 13: 108-130. 1954.
8) Burroughs, W, C. C. Culbertson, J. Kastelic, E. Cheng, and W. H. Hale, Science 120:66-67. 1954.

9) Whitehair, C.K., W.D. Callup, and M.C. BeLt, J Anim Sci 12: 331-337. 1953.

10) Fillios, L. C., Endocrinology 60: 22-27. 1957.

11) Levin, L., Endocrinology 37: 34-43. 1945.

12）加藤正戦，日内分泌誌 36: 1834-1846. 1961.

13) Loes, H. G., Proc Soc Exp Biol Med 51: 330332. 1942.

\title{
Effect of Estrogenic Substances in Herbage on the Organ Weight and Body Composition of Intact Male and Spayed Hamsters
}

\author{
Tomiharu Manda and Tatsuro Matsumoto \\ Faculty of Agriculture, Tohoku University, Sendai-shi 980
}

The data presented in the previous paper have demonstrated that the growth of intact male and spayed hamsters were accelerated by oral administration of estrogenic substances in herbage. The present paper reports the effects of oral administration of diethylstilbestrol (DES), genistin and alfalfa-extract on the organ weight and body composition of intact male and spayed hamsters.

The results were summarized as follows:

1) In the case of intact male hamsters, the growth of the body length and femur length were accelerated by DES, genistin and alfalfa-extract, and the liver weight and spleen weight were increased. DES had a depressing effect on the adrenal weight, and alfalfa-extract had an increasing effect on the weight of anterior lobe of pituitary. DES decreased the seminal vesicles weight and testes weight, whereas genistin and alfalfa-extract increased the weights of these organs.

The gains of fat and water in the treated animals were larger than those of the control. The percentage of fat increased significantly, though the percentages of water and fat-free solid in the treated animals were not different from those of the control. The increase of subcutaneous fat was particularly noteworthy.

2) The fat deposition and the weight of anterior lobe of pituitary were increased and the liver weight and the adrenal weight were decreased by spaying, though the spayed hamsters did not gain the body weight faster than the intact female hamsters.

3) In the case of spayed hamsters, DES, genistin and alfalfa-extract accelerated the growth of body length and femur length and increased the liver weight and kidney weight, however, these substances did not affect the adrenal weight and uterine weight. The percentage of fat in the treated animals increased and the increase of subcutaneous fat was most noteworthy. The percentage of fat-free solid was decreased by DES administration, though genistin and alfalfa-extract gave no effect on the percentage of fat-free solid in the spayed hamsters. 